\title{
Two new species of Anthurium sect. Urospadix (Araceae) for Brazil
}

\author{
Duas novas espécies de Anthurium sect. Urospadix Engl. (Araceae) para o Brasil
}

\author{
Lívia Godinho Temponi ${ }^{1} \&$ Marcus A. Nadruz Coelho ${ }^{2}$
}

\begin{abstract}
Two new species of Anthurium are described for Brazil, Anthurium cipoense Temponi endemic of the Serra do Cipó National Park, Minas Gerais and Anthurium polynervium Temponi \& Nadruz, endemic to municipality of Santa Maria Madalena, Rio de Janeiro state. Both have restricted distributions and studies on their conservation are needed. Descriptions, illustrations and commentaries on geographic distribution, ecology, phenology and conservation status are provided for both species.
\end{abstract}

Key words: taxonomy, Minas Gerais, Rio de Janeiro.

\section{Resumo}

Duas espécies novas de Anthurium são descritas para o Brasil, Anthurium cipoense Temponi, endêmica do Parque Nacional da Serra do Cipó, MG e Anthurium polynervium Temponi \& Nadruz, endêmica do município de Santa Maria Madalena, RJ. Ambas apresentam distribuição restrita e estudos sobre a sua conservação se fazem necessários. São fornecidas diagnoses, ilustrações e comentários sobre distribuição geográfica, ecologia, fenologia e estado de conservação das espécies aqui apresentadas.

Palavras-chave: taxonomia, Minas Gerais, Rio de Janeiro.

\section{Introduction}

Anthurium Schott is neotropical and has 1100 species, being the larger Araceae genus (Mayo et al. 1997, Govaerts \& Frodin 2002, Coelho \& Catharino 2008). Those species are distributed from northern Mexico and the Greater Antilles to southern Brazil and northern Argentina and Uruguay, occurring in open or forested habitats. They may be terrestrial, epiphyte or rupicolous (Mayo et al. 1997). Brazil, with about 130 Anthurium species, is a country with great diversity in this genus (Coelho et al. 2010).

Anthurium is divided into 18 sections (Croat $\&$ Sheffer 1983), some of which have been revised and re-circumscribed (e.g. Croat 1991). Anthurium sect. Urospadix was interpreted differently by Engler $(1878,1898,1905)$ and Croat \& Sheffer $(1983$, 2002), but according to these authors, the section has a disjunct distribution, with several species in Central America and western South America, and others in the eastern Brazil.

Based on morphological and molecular studies, Temponi (2006) proposes the recircumscription of Anthurium sect. Urospadix, restricting this group to 60 species of usually ground herbs, with short internodes, up to $0.5 \mathrm{~cm}$ long, simple leaves, with brochidrodome venation and interprime veining, trichomes usually present at the funiculus and distribution restricted to eastern Brazil.

During the survey of this group of Anthurium sect. Urospadix Engl. Brazilian species, two new species were recognized and are described here. Since they are species of local occurrence and few populations, they are considered to be vulnerable according to the IUCN criteria (2010), and studies on their preservation are therefore required.

\footnotetext{
${ }^{1}$ Universidade Estadual do Oeste do Paraná, R. Universitária, 2069, Jardim Universitário, 85819-110, Cascavel, PR, Brasil. liviatemponi@yahoo.com.br ${ }^{2}$ Instituto de Pesquisas do Jardim Botânico do Rio de Janeiro, R. Pacheco Leão 915, 22460-030, Rio de Janeiro, RJ, Brasil.
} 


\section{Material and Methods}

To perform this study, samples of Anthurium cipoense and Anthurium polynervium, as well some closed species were examined in the BHCB, MO, K, $\mathrm{RB}, \mathrm{SP}, \mathrm{SPF}$ herbaria (acronyms in accordance with Thiers 2010). The morphological description of the vegetative and reproductive structures followed terminology presented in Madison (1977), Radford et al. (1974), Croat \& Bunting (1979), Mayo (1991) and Mayo et al. (1997).

Anthurium cipoense Temponi, sp. nov. Type: BRAZIL. MINAS GERAIS: Santana do Riacho, Parque Nacional da Serra do Cipó, 19¹6'1.2''S, 4333'5.5'”'W, elev. 1,220 m. 22.XII.2004, fr., Temponi et al. 384 (holotype SPF!; isotype K!, RB!).

Figs. 1a-c, 2a-d

Anthurium cipoense Temponi sp. nov. Anthurio megapetiolato E.G. Gonç. habitu terrestri, foliorum laminae nervis in paginam adaxialem insculptis affinis, sed petiolo breviori (nec longo), foliorum lamina anguste elliptica usque elliptica (nec oblonga usque oblongo-elliptica), nervis secundariis paucis (nec ultra 14 utroque costae latere), floribus paucis in quoque spira manifestis (nec multior) differt.

Terrestrial. Erect stem; short internodes, totally covered by the sylleptic prophylls and mesophylls; brownish, persistent, entire prophylls and mesophylls. Leaf with slightly reddish, cylindrical to slightly adaxially furrowed petiole, 18 $30.9 \times 0.15-0.3 \mathrm{~cm}$; geniculum $0.4-2.1 \mathrm{~cm}$ long, thicker, concolor slightly lighter than the petiole; erect, chartaceous, strongly discolored greenish leaf blade, narrowly elliptical to elliptical, acute apex, obtuse base, 19-27.3 ×4.8-11.1 cm; adaxially acute, abaxially obtuse primary veins; secondary veins strongly prominent adaxial, 7-9 on both sides; collecting veins $0.5-1.5 \mathrm{~cm}$ away from the margin; no basal veining. Inflorescence with erect, vinaceous, cylindrical peduncle, $25.5-43 \times 0.12-0.15 \mathrm{~cm}$; vinaceous, deflexed spathe, forming an acute angle at the junction with the peduncle, decurrent leaf $0.6 \mathrm{~cm}$ long, $3 \times 0.4 \mathrm{~cm}$; spadix, 5.3-17.4 $\times 0.63$ $1.45 \mathrm{~cm}$, shortly stipitate, stipe $0.3 \mathrm{~cm}$ long, 4-5 flowers at the primary spiral, 3 at the secondary spiral; tepals $1.8-2.2 \times 1 \mathrm{~mm}$, stamens $1.5-2 \times 0.7-$ $0.8 \mathrm{~mm}$, apocarp $1.9 \times 1.65 \mathrm{~mm}$, brown stigma, bilocular ovary, one ovule per locule, axile-apical placentation. Green berries with vinaceous apex.

Anthurium cipoense is related to Anthurium megapetiolatum E.G. Gonç., and they share the same terrestrial habit and strong veining on the adaxial side; however, it differs from the latter species by having a short petiole, no longer than $32 \mathrm{~cm}$, narrowly elliptical to elliptical leaf blade, with 7-9 secondary veins on both sides and 4-5 flowers on the primary spiral and 3 on the secondary spiral; while A. megapetiolatum has a long petiole, up to $81 \mathrm{~cm}$ in length, oblong to oblong-elliptical leaf blade, with 14-18 secondary veins on both sides and 4-9 flowers on the primary spiral and 4-5 on the secondary spiral of the spadix.

The specific epithet honors the collection site, Serra do Cipó National Park, which is home to outcrops and also to areas with still unexplored riparian forest, where forest interior species such as A. megapetiolathum (Gonçalves, 2001) and A. cipoense are still being discovered and described.

Anthurium polynervium Temponi \& Nadruz, $s p$. nov. Type: BRAZIL. RIO DE JANEIRO, Santa Maria Madalena, Macuco to Santa Maria Madalena roadway, near the cloverleaf interchange to São Sebastião do Alto, 22 ${ }^{\circ} 0^{\prime} 14.04 " \mathrm{~S}, 42^{\circ} 41^{\prime} 23.99 " \mathrm{~W}$, 24.VII.2006, fl. and fr., Temponi et al. 429 (holotype RB!; isotype SPF!, K!, MO!). $\quad$ Figs. 1d-f, 2e-g

Anthurium polynervium Temponi \& Nadruz sp. nov. Anthurio augustino K. Koch \& Lauche affinis, sed foliorum lamina lanceolata, oblonga usque elliptica (nec ovato-lanceolata), nervis basalibus 1-2 (nec 3), nervis secundariis 17-26 (nec 24-30) differt.

Terrestrial, rupicolous, saxicolous. Erect stem; very short internodes, totally covered by the prophylls and mesophylls; greenish prophylls and mesophylls, entire when young, becoming brown, decomposed in a fibrous mass, persistent from the apex to the stem base. Leaf with greenish petiole, cylindrical to slightly adaxialy furrowed when young and furrowed cylindrical, with adaxially obtuse margins in adult individuals, $19.5-43.8 \times 0.22-56 \mathrm{~cm}$; thicker geniculum, concolor and slightly lighter then the petiole, $0.4-2.1 \mathrm{~cm}$ long; erect, chartaceous, discolored greenish, lanceolate, oblong to elliptical leaf blade, with acute apex, shortly apiculate, subcordate base, with slightly decurrent blade, spatulate posterior lobes $1 / 15-1 / 56$ of the blade length, 25.1$61.5 \times 7-20.8 \mathrm{~cm}$; obtuse to rarely adaxially acute primary veins on both faces; secondary veins visible only adaxially, slightly abaxially prominent, $17-26$ on both sides; collecting veins emerging over the blade base, $0.5-1.3 \mathrm{~cm}$ from the margin; $1-2$ basal veins on 


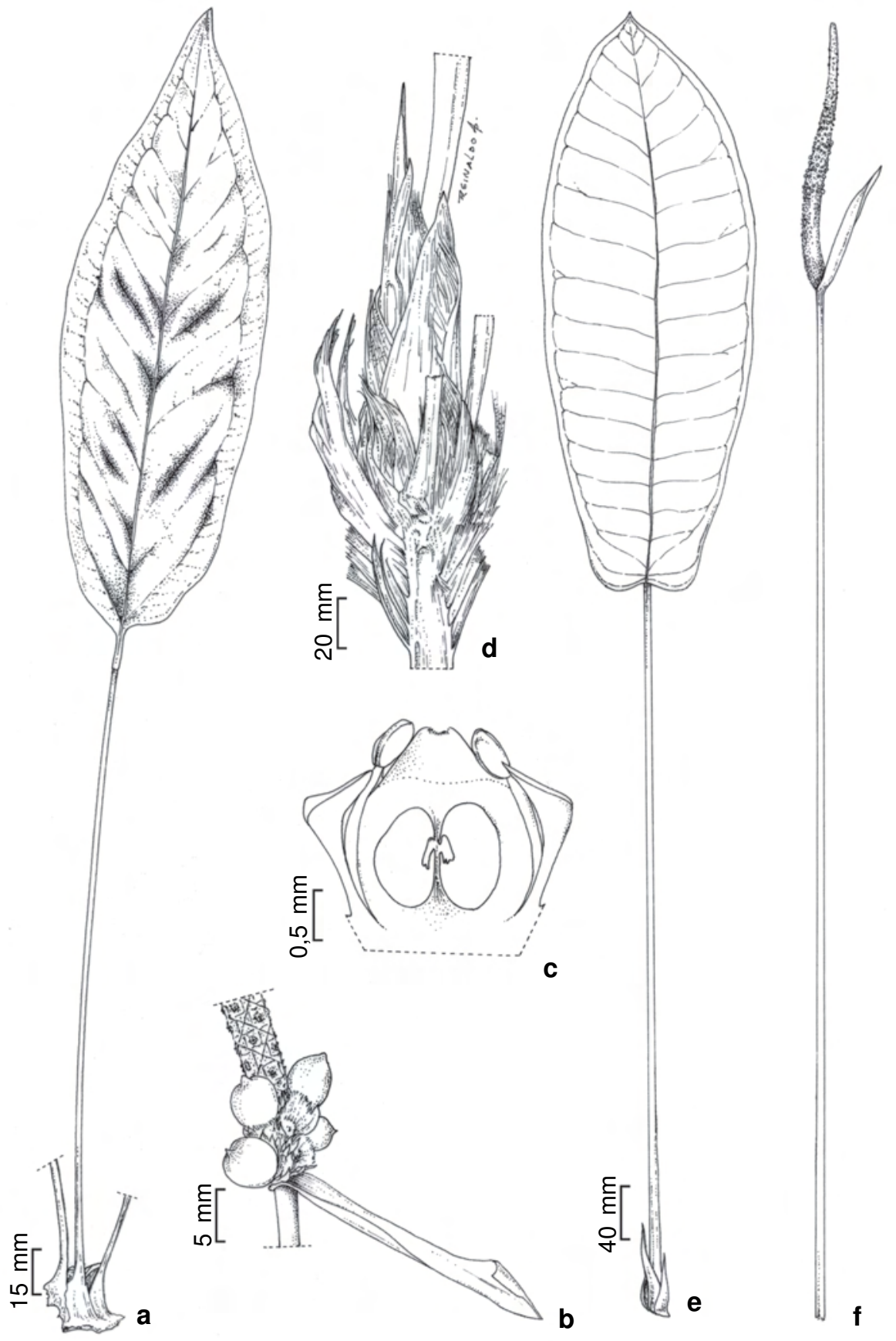

Figure 1 - Two new species of Anthurium sect. Urospadix Engl. (Araceae) for Brazil. a-c. Anthurium cipoense Temponi (Temponi 384) - a. leaf with few secondary veins, sunken above, collective veins $0.5-1.5 \mathrm{~cm}$ from the margins and absence of basal veins; b. spadix with berries mature exerted from tepals; c. 2-locular ovary, one ovule per locule, axile-apical placentation near apex of septum. d-f. Anthurium polynervium Temponi \& Nadruz (Temponi et al. $356)$ - d. erect stem; very short internodes, persistent mesophylls and prophylls at upper internodes, decomposing in brown fibers; e. erect leaf blade, sharp apex, shortly apiculate, sub-cordate base, numerous secondary veins and basal veins 1-2 on both sides; f. spadix with erect peduncle and spadix sessile. 

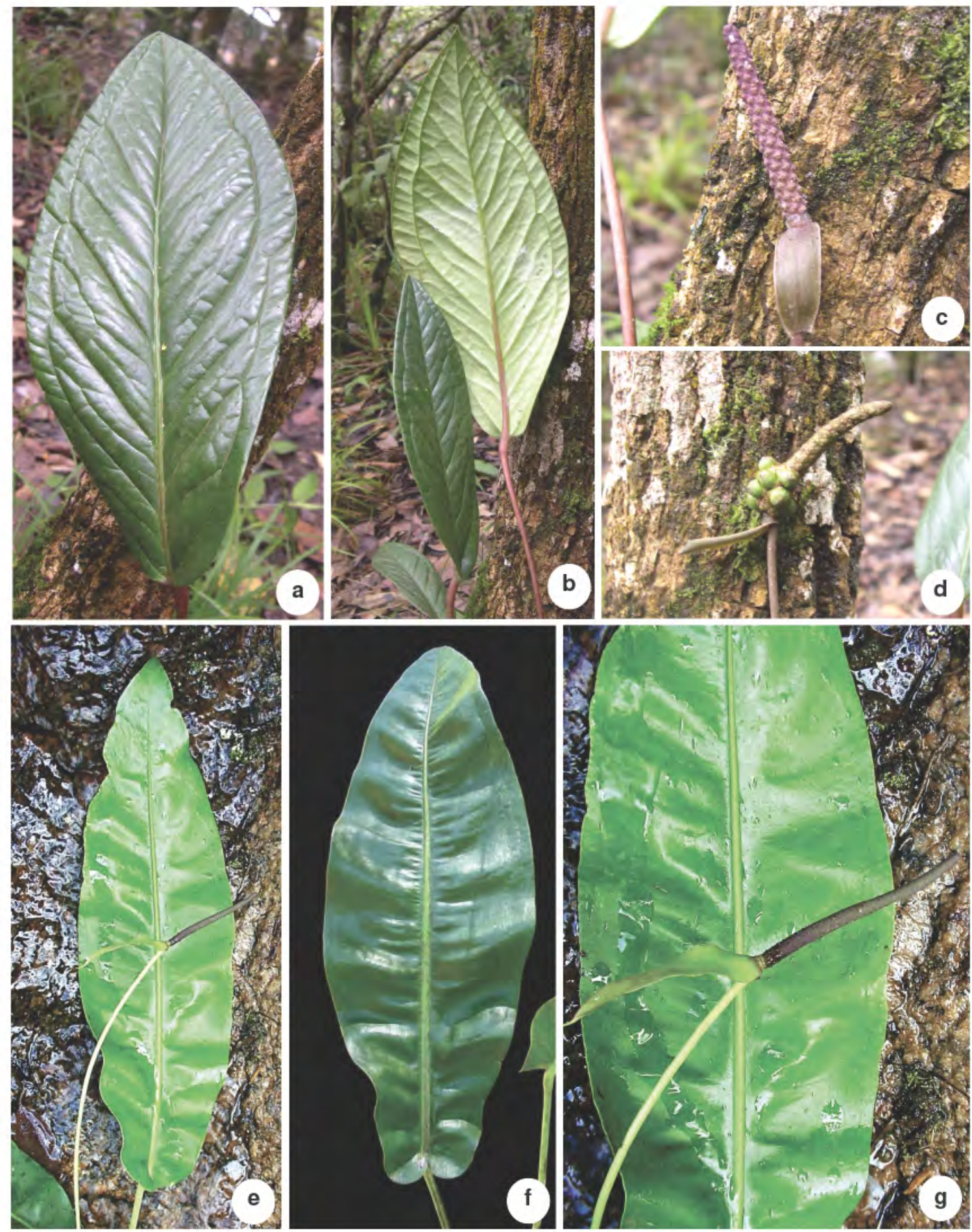

Figure 2 - Two new species of Anthurium sect. Urospadix Engl. (Araceae) for Brazil. a-d. Anthurium cipoense Temponi - a. leaf with few secondary veins, suken above; b. light green leaf down, purple petiole and midrib; c. spadix at floration; d. spadix at fruition. e-g. Anthurium polynervium Temponi \& Nadruz - e.blade erect; $\mathrm{f}$. blade with apex acute, shortly apiculate, sub-cordate base; g. spadix sessile. 
both sides, the outermost extending to the base of the posterior lobe, the innermost ending at the margin of the leaf blade lower quarter. Inflorescence with erect, greenish, cylindrical to slightly flat peduncle, 21.5$74.4 \times 0.2-0.24 \mathrm{~cm}$; greenish to vinaceous spathe, forming a right, obtuse to acute angle with the peduncle, decurrent leaf 0.6 long, 5.4-11.7 ×0.8-1.3 $\mathrm{cm}$; sessile, greenish to vinaceous stipitate, 5.3$17.4 \times 0.63-1.45 \mathrm{~cm} ; 8-9$ flowers on the primary spiral, 6 on the secondary spiral; hooded tepals with rough walls, side tepals slightly concave and dorsally acute; front and rear tepals strongly ventrally concave and dorsally sub-carinate to carinated, $1.1-1.5 \mathrm{~mm}$; stamens 1.6-1.9 ×0.5-0.8 mm; apocarp $1.3 \times 0.8-$ $1.1 \mathrm{~mm}$, inconspicuous stigma, oblong, bilocular ovary, one ovule per locule, axile-apical placentation. Creamy-green berries with dark purple apex.

Species endemic to the state of Rio de Janeiro, occurring only in the Santa Maria Madalena municipality, between 756 and $964 \mathrm{~m}$ altitude, in dense rain forest. This is an ombrophilous and rare species. Collected with flower and fruit in October. Material examined: BRAZIL. RIO DE JANEIRO: Santa Maria Madalena, cultivado no Jardim Botânico do Rio de Janeiro, 28.IX.2005, M. Nadruz 1644 (RB); $22^{\circ} 0$ '2.88'S $42^{\circ} 7$ '0.98''W, 17.VI.2004, fl. and fr., Temponi et al. 356 (SPF); Fazenda Dubois, 21 '56'53"S 41'59'29"W, 28.X.2004, fl. and fr., J.M. Braga 7511 (RB).

Anthurium polynervium is related to Anthurium augustinum C. Koch \& Lauche by having a lanceolate, oblong to elliptical leaf blade, 1-2 basal veins and 17-26 secondary veins, while A. augustinum has an ovate-lanceolate leaf blade, 3 basal veins and 24-30 secondary veins.

The specific epithet refers to the large number of secondary veins on both sides; although being only adaxially visible, slightly abaxially prominent, the large number of secondary veins gives a wavy appearance to the leaf surface.

The diversity of Anthurium sect. Urospadix species in Brazil has been verified in recent studies. Over the past 20 years, 23 new species have been described (Sakuragui \& Mayo 1999; Coelho \& Mayo 2000; Mayo et al. 2000; Sakuragui 2000; Gonçalves 2001; Coelho \& Leoni 2004; Coelho \& Catharino 2005; Coelho \& Croat 2005; Gonçalves 2005; Coelho 2006; Coelho \& Catharino 2008; Gonçalves \& Jardim 2009; Catharino \& Coelho 2010). Moreover, nine species are being described for Bahia and Espírito Santo, totalling 32 recently discovered species for Anthurium sect. Urospadix, a section almost exclusive to the Atlantic Forest.
Since this is a group of probably recent diversification, specific differences are usually small. Less widely used characteristics for the distinction of species of other Anthurium sections, such as primary veining shape, habit, internode length, color and degree of decomposition of cataphylls and prophylls (Coelho et al. 2009), as well as anatomical characteristics of the leaf and spathe (Mantovani et al. 2010), have proven to be important for the recognition of these species. Thus, taxonomic studies must continue, to include population studies, since the diversification of the group suggests an adaptation to different microenvironments of eastern Brazil.

\section{Acknowledgments}

The authors thank Reinaldo Antônio Pinto for illustrations of the species here described, the Conselho Nacional de Desenvolvimento Científico e Tecnológico (CNPq) fellowship (bolsa de doutorado) and Simon J. Mayo for writing the Latin diagnosis.

\section{Referências}

Catharino L.E.M. \& Coelho, M.A.N. 2010. Uma espécie nova de Anthurium Schott (Araceae), endêmica na Serra da Bocaina, município de Bananal, São Paulo, Brasil Rodriguésia 61: 69-72.

Coelho, M.A.N. 2006. New species of Anthurium (Araceae) from Brazil. Aroideana 29: 91-103.

Coelho, M.A.N. \& Catharino, L.E.M. 2005. Duas espécies novas de Anthurium Schott (Araceae) para o Brasil. Rodriguesia 56: 35-42.

Coelho, M.A.N. \& Catharino, E.L.M. 2008. Duas novas espécies de Anthurium (Araceae) endêmicas do litoral de São Paulo, Brasil. Rodriguésia 59: 829-833.

Coelho, M.A.N. \& Croat, T.B. 2005. A new endemic species of Anthurium (Araceae) from Brazil. Aroideana 28: 65-68.

Coelho, M.A.N. \& Leoni, L.S. 2004. Duas espécies novas de Anthurium Schott (Araceae) para o Brasil. Pabstia 15: 1-9.

Coelho, M.A.N. \& Mayo, S.J. 2000. Anthurium maricense Nadruz \& Mayo - a new species of Anthurium Schott (Araceae: tribe Anthurieae) for Brazil. Aroideana 23: 82-87.

Coelho, M.A.N.; Soares, M. L., Sakuragui; C.M., Mayo, S.; Andrade, I.M. \& Temponi, L.G. 2010. Araceae in Lista de espécies da flora do Brasil. Available in $<$ http://floradobrasil.jbrj.gov.br/2010>. Accessed on 12 mai 2010.

Coelho, M.A.N.; Waechter, J.L. \& Mayo, S.J. 2009. Revisão taxonômica das espécies de Anthurium (Araceae) seção Urospadix subseção Flavescentiviridia. Rodriguesia 60: 799-864. 
Croat, T.B. 1991. A revision of Anthurium section Pachyneurium (Araceae). Annals of the Missouri Botanical Garden 78: 539-855.

Croat, T.B. \& Bunting, G.S. 1979. Standardization of Anthurium descriptions. Aroideana 2: 15-25.

Croat, T.B. \& Sheffer, R.B. 1983. The sectional groupings of Anthurium (Araceae). Aroideana 6: 85-123.

Croat, T.B. \& Sheffer, R.B. 2002. The sectional groupings of Anthurium (Araceae). Available in <http:// www.aroid.org/genera/Anthurium/anthsections $>$. Accessed on 12 oct 2002.

Engler, H.G.A. 1878. Araceae. In: Martius, C. F. P. Von. Flora brasiliensis. München, Tipografia Regia. 3: 25-224, tabs 2-52.

Engler, H.G.A. 1898. Revision der Gatting Anthurium Schott. Botanische Jahrbücher für Systematik 25: 352-476.

Engler, H.G.A. 1905. Araceae-Pothoideae. In: Engler, H.G.A. Das Pflanzenreich Berlin, W. Engelmann, 4: $1-330$.

Gonçalves, E.G. 2001. A new Anthurium (Araceae) from Serra do Cipó, Brazil. Aroideana 24: 6-12.

Gonçalves, E.G. 2005. A new species of Anthurium (Araceae) from Espirito Santo State, eastern Brazil. Feddes Repertorium 116: 92-95.

Gonçalves, E.G \& Jardim, J.G. 2009. Two new species of Anthurium (Araceae) from Brazil. Kew Bulletin 64: 713-717.

Govaerts, R. \& Frodin, D. 2002. World checklist and bibliography of Araceae (and Acoraceae). Royal Botanic Gardens, Kew. 560p.

IUCN Red List Categories and Criteria. Version 8.0. Prepared by the Standards and Petitions, Subcommittee in
March 2010. Available in <http://intranet.iucn. org/ webfiles/doc/SSC/RedList/RedListGuidelines. pdf $>$. Accessed on 10 may 2010.

Madison, M.T. 1977. A revision of Monstera (Araceae). Contributions from the Herbarium Harvard University 207: 1-101.

Mantovani, A.; Filartiga, A.L.P. \& Coelho, M.A.N. 2010. Anatomia comparada de folha e espata de espécies de Anthurium (Araceae) ocorrentes na Mata Atlântica. Revista Brasileira de Botânica 33: 185-200.

Mayo, S.J. 1991. A revision of Philodendron subgenus Meconostigma (Araceae). Kew Bulletin 46: 601-681.

Mayo, S.J.; Bogner, J. \& Boyce, P.C. 1997. The genera of Araceae. Royal Botanic Gardens, Kew. 370p.

Mayo, S.J.; Felix, L.P.; Jardim, J.G. \& Carvalho, A.M. 2000. Anthurium bromelicola - a remarkable new species from Northeast Brazil. Aroideana 23: 89-99.

Radford, A.E.; Dickison, W.C.; Massey, J.R. \& Bell, C.R. 1974. Vascular plant systematics. Harper \& Row, New York. 891p.

Sakuragui, C.M. 2000. Araceae of campos ruspestres of Cadeia do Espinhaço in Minas Gerais state, Brazil. Aroideana 23: 56-81.

Sakuragui, C.M. \& Mayo, S. 1999. A new species of Anthurium (Araceae) from south-eastern Brazil. Feddes Repertorium 110: 535-539.

Temponi, L.G. 2006. Sistemática de Anthurium seção Urospadix (Araceae). Tese de Doutorado. Universidade de São Paulo, São Paulo. 143p.

Thiers, B. 2010. Index Herbariorum. Part I: The herbaria of the world. Available in <http://sweetgum.nybg. org/ih/>. Accessed on 18 jun 2010. 